Research article

\title{
Comparison of polyamine metabolism in tomato plants exposed to different concentrations of salicylic acid under light or dark conditions
}

\author{
Zoltán Takács, Péter Poór, Irma Tari* \\ Department of Plant Biology, University of Szeged, H-6726 Szeged, Közép Fasor 52., Hungary
}

\section{A R T I C L E I N F O}

\section{Article history:}

Received 1 June 2016

Received in revised form

19 July 2016

Accepted 19 July 2016

Available online 20 July 2016

\section{Keywords:}

Dark

Hydrogen peroxide

Light

Nitric oxide

Polyamine

Salicylic acid

Tomato

\begin{abstract}
A B S T R A C T
In this study the effect of exogenous $0.1 \mathrm{mM}$ and $1 \mathrm{mM}$ salicylic acid (SA) treatments were investigated on polyamine (PA) metabolism in tomato (Solanum lycopersicum L. cv. Ailsa Craig) leaves in illuminated or dark environments. The former proved to be sublethal and the latter lethal concentration for tomato leaf tissues. While PA biosynthetic genes, arginine- and ornitine decarboxylases or spermidine- and spermine synthases were highly up-regulated by $1 \mathrm{mM} \mathrm{SA}$, the enzymes participating in PA catabolism, diamine(DAOs, EC 1.4.3.6) and polyamine oxidases (PAOs, EC 1.5.3.3) displayed higher transcript abundance and enzyme activity at $0.1 \mathrm{mM} \mathrm{SA}$. As a result, putrescine and spermine content but not that of spermidine increased after $1 \mathrm{mM}$ SA application, which proved to be higher in the dark than in the light. $\mathrm{H}_{2} \mathrm{O}_{2}$ content produced on the effect of $1 \mathrm{mM}$ SA was significantly higher than at $0.1 \mathrm{mM}$ SA in the light. Since there was no coincidence between $\mathrm{H}_{2} \mathrm{O}_{2}$ accumulation and terminal PA catabolism, reactive oxygen species produced by photosynthesis and by other sources had more pronounced effect on $\mathrm{H}_{2} \mathrm{O}_{2}$ generation at tissue level than DAOs and PAOs. Accordingly, $\mathrm{H}_{2} \mathrm{O}_{2}$ in the absence of NO accumulation contributed to the initiation of defence reactions after $0.1 \mathrm{mM} \mathrm{SA}$ treatment, while high SA concentration generated simultaneous increase in $\mathrm{H}_{2} \mathrm{O}_{2}$ and $\mathrm{NO}$ production in the light, which induced cell death within $24 \mathrm{~h}$ in illuminated leaves. However, the appearance of necrotic lesions was delayed in the absence of NO if these plants were kept in darkness.
\end{abstract}

(c) 2016 Published by Elsevier Masson SAS.

\section{Introduction}

Polyamines (PAs) are low molecular weight organic compounds which can be found from bacteria to plants and animals. Changes in free PAs and their catabolism have been shown to occur in incompatible interactions between plants and pathogens. A common feature of these interactions is an increase in apoplastic $\mathrm{H}_{2} \mathrm{O}_{2}$, which triggers hypersensitive response (HR) (Jiménez-Bremont et al., 2014). Enzymes participating in terminal PA catabolism may contribute to this oxidative burst, but the relationship between salicylic acid (SA), the signalling compound in HR and PA

Abbreviations: ADC, arginine decarboxylase; DAO, diamine oxidase; EL, electrolyte leakage; HR, hypersensitive response; MDA, malondialdehyde; NO, nitric oxide; ODC, ornithine decarboxylase; PAs, polyamines; PAO, polyamine oxidase; Put, putrescine; ROS, reactive oxygen species; SAR, systemic acquired response; Spd, spermidine; SPDS, spermidine synthase; Spm, spermine; SPMS, spermine synthase; TMV, tobacco mosaic virus.

* Corresponding author.

E-mail addresses: takacszoltan8923@gmail.com (Z. Takács), poorpeti@bio.uszeged.hu (P. Poór), tari@bio.u-szeged.hu (I. Tari). metabolism has not yet been revealed in full details.

PAs have two or more amine groups, and the most common PAs in plant kingdom are the diamine putrescine (Put), the triamine spermidine (Spd) and the tetraamine spermine (Spm). The relative abundance of PAs depends on species and developmental stage of plants and higher accumulation of PAs were detected in actively growing tissues or in tissues exposed to biotic- or abiotic stresses (Jiménez-Bremont et al., 2014). It is well known that PAs have cationic nature at cellular $\mathrm{pH}$ and can interact with the negatively charged functional groups of macromolecules and membranes. Thus, PAs can stabilize plant cell membranes by reducing ion leakage from cells and they also alleviate lipid peroxidation under stress conditions (Borrel et al., 1997). PA levels, the expression of the genes participating in PA biosynthesis and the activity of PA metabolic enzymes were augmented by microbial colonization in the infected tissues, which were independent of the biotrophic or necrotrophic nature of pathogens (Jiménez-Bremont et al., 2014).

The biosynthesis of PAs in plants is well documented: the decarboxylation of arginine or ornithine is catalyzed by arginine decarboxylase (ADC, EC 4.1.1.19) or ornithine decarboxylase (ODC, 
EC 4.1.1.17), respectively to yield ultimately diamine Put. Spd and Spm are formed by the sequential addition of aminopropyl groups to Put and Spd, respectively, from S-adenosylmethionine (SAM) decarboxylated by SAM decarboxylase (SAMDC, EC 4.1.1.50) (Moschou et al., 2012). These reactions are catalyzed by the aminopropyltransferase enzymes, spermidine synthase (SPDS, EC 2.5.1.16) and spermine synthase (SPMS, EC 2.5.1.22). ADC is mainly located in the chloroplast in actively photosynthesizing tissues and it is directed to the nucleus in non-photosynthetic cells (Borlotti et al., 2004), while ODC is a cytosolic enzyme. SPDS and SPMS are localized in the cytoplasm or in the nucleus, but SAMDC is mostly cytoplasmic (Belda-Palazón et al., 2012). The over-expression of PA biosynthesis genes resulted in higher PA levels and enhanced resistance against various pathogen infections. Furthermore, it has been shown that resistant barley cultivars accumulated more Put and Spd than the susceptible ones following the infection with Blumeria graminis f. sp. hordei (Cowley and Walters, 2002).

PA catabolism is mediated by two known enzyme groups, diamine oxidases (DAOs, EC 1.4.3.6) and polyamine oxidases (PAOs, EC 1.5.3.3). DAOs show a preference for Put, and have low affinity for Spd and Spm while PAOs oxidize mainly Spd and Spm and are involved in the terminal catabolism and back conversion pathways of their substrates (Moschou et al., 2012). The oxidation of Put by DAOs and that of Spd and Spm by PAOs generate $\mathrm{H}_{2} \mathrm{O}_{2}$ and those isoenzymes that are directed to the apoplast (e.g. AtCuAO1 and ZmPAO1 in the Arabidopsis and maize, respectively) contribute to the apoplastic burst of reactive oxygen species (ROS) and to HR promoting resistance against invading pathogens (Planas-Portell et al., 2013). In plant reactions against microbes, $\mathrm{H}_{2} \mathrm{O}_{2}$ participates in structural defence by cell wall strengthening and it also functions as an antimicrobial compound in the apoplast. The substrate of apoplastic PAO was Spd, which accumulated in the apoplast during HR elicitation in tobacco infected with tobacco mosaic virus (TMV) (Yoda et al., 2003, 2006). Many studies have shown that the catabolic processes of PAs were activated by increased activity of DAOs and PAOs following the accumulation of free PAs (Cowley and Walters, 2002).

Furthermore, it was shown in tomato protoplasts that exogenous application of Spd and Spm increased nitric oxide (NO) production of the tissues (Gémes et al., 2011). Thus, the generation of NO, the other key mediator of plant defence or inducer of cell death was suggested to be a component of PA action. The production of $\mathrm{H}_{2} \mathrm{O}_{2}$ deriving from $\mathrm{PA}$ catabolism combined with $\mathrm{NO}$ accumulation may play an important signalling role in plant-pathogen interactions (Romero-Puertas et al., 2004).

PA metabolism can be modulated by phytohormones, such as SA (Jiménez-Bremont et al., 2014). Although the role of SA in plant defence responses against biotrophic pathogens is well-established (Hayat et al., 2010), the current information concerning the relationship between SA and PA metabolism is far from complete. It was revealed that exogenously applied SA induced PA accumulation in maize (Németh et al., 2002) and in tomato (Szepesi et al., 2009) and it was able to activate the expression of $A D C$ and $O D C$ in tomato plants (Zhang et al., 2011). However, the SA-induced defence reactions such as the release of ROS proved to be light-dependent and light was also required for the induction of HR (Genoud et al., 2002). Zeier et al. (2004) reported that SA accumulation and SAinduced expression of PATHOGENESIS-RELATED CLASS 1 (PR1) genes were also light-dependent when Arabidopsis plants were inoculated with an avirulent strain of Pseudomonas syringae. HR was significantly reduced in the dark and plants infected in the dark period showed reduced lesion formation in response to non-host and avirulent pathogens (Chandra-Shekara et al., 2006). Local accumulation of SA after infection can induce the systemic acquired resistance (SAR), a form of induced resistance, which is a "whole- plant" response that occurs following a localized exposure to a pathogen (Mishina and Zeier, 2007).

The analysis of promoter sequences of two PAO (ZMPAO1 and ZMPAO2) encoding genes in Zea mays suggested that they can also be regulated by light, suggesting the possibility of the transcriptional control of PAO expression by light (Cervelli et al., 2000). In the relationship between SA and PA accumulation or metabolism, light/dark conditions proved to be very significant because many fungal pathogens or herbivores are less active during the day and plants should improve the protection against these attackers in the dark (Gilbert and Reynolds, 2005).

Along with apoplastic oxidative burst caused by HR, illuminated chloroplasts are also sources of ROS generated unavoidably with photosynthetic electron flow. The most important ROS are produced around photosystems: PSII is a main source of singlet oxygen $\left({ }^{1} \mathrm{O}_{2}\right)$, and superoxide anion radical $\left(\cdot \mathrm{O}_{2}^{-}\right)$and $\mathrm{H}_{2} \mathrm{O}_{2}$ are produced around PSI. ${ }^{1} \mathrm{O}_{2}$ and $\mathrm{H}_{2} \mathrm{O}_{2}$ play also a role in retrograde signals to regulate the expression of nuclear-encoded defence genes (Karpiński et al., 2013) and HR (Jelenska et al., 2007).

Exogenous SA treatment can induce acclimation to various biotic (Bechtold et al., 2005) and abiotic stresses (Hayat et al., 2010) or it can induce cell death by various signalling pathways, including ROS and NO (Poór et al., 2013). In this study, tomato plants were treated with $0.1 \mathrm{mM}$ and $1 \mathrm{mM}$ SA concentrations through the root system. The concentration dependency of SA effect has been revealed by a number of authors (Caarls et al., 2015; Horváth et al., 2015). In our earlier works it was found that $0.1 \mathrm{mM}$ SA applied through the root system proved to be sublethal, while at $1 \mathrm{mM}$ it induced cell death and HR-like necrotic spots in the leaves of tomato (Poór et al., 2011). The aim of this work was to reveal the differences in PA metabolism in the plants exposed to different concentrations of SA, if the tissues survive or if cell death is initiated. Moreover, the common features and differences in the early events of SA-induced PA metabolism were compared in illuminated plants and in plants exposed to 24-h dark period in order to reveal significance of terminal PA oxidation and $\mathrm{H}_{2} \mathrm{O}_{2}$ production in photosynthesizing tissues.

\section{Materials and methods}

\subsection{Plant materials and growth conditions}

Seeds of tomato plants (Solanum lycopersicum L. cv. Ailsa Craig) were germinated at $26{ }^{\circ} \mathrm{C}$ for three days in the dark, and the seedlings were subsequently transferred to perlite for two weeks. The plants were then placed in a hydroponic culture as described by Poór et al. (2011). The nutrient solution was changed three times a week. Plants were grown in a controlled environment under $200 \mu \mathrm{mol} \mathrm{m}{ }^{-2} \mathrm{~s}^{-1}$ photon flux density (F36W/GRO lamps, OSRAM SYLVANIA, Danvers, MA, USA), with 12/12 h light/dark period, a day/night temperatures of $24 / 22{ }^{\circ} \mathrm{C}$ and a relative humidity of $55-60 \%$ for eight weeks.

Tomato plants were treated with $0.1 \mathrm{mM}$ or $1 \mathrm{mM}$ SA supplied in the nutrient solution for $24 \mathrm{~h}$ and were kept under the same 12/ $12 \mathrm{~h}$ light/dark period and growth condition as they had been grown previously. Half of the plants were placed into darkroom of the same temperature and humidity after SA treatments for the next $24 \mathrm{~h}$. The uptake and accumulation of SA was not significantly different in illuminated and dark-treated plants and it reached $\sim 5 \mu \mathrm{g} \mathrm{g}^{-1}$ fresh mass at $0.1 \mathrm{mM} \mathrm{SA}$ and $\sim 60 \mu \mathrm{g} \mathrm{g}^{-1}$ fresh mass at $1 \mathrm{mM}$ SA (unpublished data). Samples were prepared from the second, fully expanded young leaves in three replicates $1 ; 3 ; 6 ; 12$; $24 \mathrm{~h}$ after the different SA treatments. The experiments were conducted from 9 a.m. for $24 \mathrm{~h}$ and were repeated three times in same condition. 


\subsection{Determination of electrolyte leakage and malondialdehyde (MDA) content}

Electrolyte leakage (EL) was determined as described previously (Poór et al., 2013). Relative EL expresses the actual conductivity (C1) as a percentage of total conductivity $(C 2)\left(E L(\%)=\left(C_{1} / C_{2}\right) \times 100\right)$. Lipid peroxidation was estimated by measuring the thiobarbituric acid-reactive substances (TBARS) (Horváth et al., 2015).

\subsection{Measurement of free polyamine levels}

Free PA contents were determined as described by Szepesi et al. (2009). In brief, $200 \mathrm{mg}$ of leaf samples were homogenized in 5\% perchloric acid. After centrifugation, $2.5 \mathrm{~mL}$ of the supernatant was neutralized with $1 \mathrm{~mL}$ of $2 \mathrm{M} \mathrm{NaOH}$, and the PAs were derivatized with $10 \mu \mathrm{L}$ of benzoyl chloride. The benzoyl-PA derivates were extracted from the aqueous phase with diethyl ether. The organic phase was evaporated to dryness. The PAs were separated by highperformance liquid chromatography (HPLC) with a mixture of acetonitrile/water (45/55, v/v) (Carlo Erba, Rodano, Italy) on a reverse-phase column (Apex octadecyl, $5 \mu \mathrm{m} ; 250 \mathrm{~mm} \times 4.6 \mathrm{~mm}$ ) at $25^{\circ} \mathrm{C}$ (JASCO HPLC System, Tokyo, Japan), and monitored with UV detector at $254 \mathrm{~nm}$. The applied standards were Put, Spd, and Spm in the form of hydrochlorides (Sigma-Aldrich, St. Louis MO, USA).

\subsection{RNA extraction and gene expression analyses with real-time $R T-P C R$}

The expression rate of the genes participating in PA biosynthesis and catabolism were determined by quantitative real-time PCR (Piko Real-Time qPCR System, Thermo Scientific) using SYBR green dye after the extraction of RNA from $100 \mathrm{mg}$ plant leaves according to (Horváth et al., 2015). Genomic DNA digestions were performed by DNas I (Fermentas UAB, Vilnius, Lithuania) and first strand cDNA was synthesized using MMLV reverse transcriptase (Fermentas UAB, Vilnius, Lithuania). Tomato genes were mined from Sol Genomics Network (SGN) database (http://solgenomics.net/). Primers were designed using NCBI (http://www.ncbi.nlm.nih.gov/) and Primer 3 software (http://frodo.wi.mit.edu/) on the selected genes (Table 1 ). The PCR reaction mixture consisted of $5 \mu \mathrm{L}$ of Maxima SYBR Green qPCR Master Mix (2×) (Thermo Scientific), $400 \mathrm{nM}$ forward and reverse primers, $10 \mathrm{ng}$ of cDNA template, and nuclease-free water in a total volume of $10 \mu \mathrm{L}$. The two-step RT-PCR was performed with the following program: one cycle of $95^{\circ} \mathrm{C}$ for $7 \mathrm{~min}$, followed by 40 cycles of denaturation at $95^{\circ} \mathrm{C}$ for $15 \mathrm{~s}$ and annealing extension at $60^{\circ} \mathrm{C}$ for $59 \mathrm{~s}$. To determine the specificity of the reaction, a melting curve analysis of the product was performed immediately after the final PCR cycle by increasing the temperature from 55 to $90{ }^{\circ} \mathrm{C}\left(0.2{ }^{\circ} \mathrm{C} \mathrm{s}^{-1}\right)$. Data analysis was performed using PikoReal Software 2.2 (Thermo Scientific). The tomato 18S rRNA and elongation factor- $1 \alpha$ subunit $(E F 1-\alpha)$ genes were used as reference genes. Each reaction was repeated at least three times.

\subsection{Determination of terminal diamine- and polyamine oxidase activities}

DAO (EC 1.4.3.6) and PAO (EC 1.4.3.4) activities were estimated spectrophotometrically with minor modifications of the method described by Quinet et al. (2010). $200 \mathrm{mg}$ of excised leaf tissues were homogenized in liquid $\mathrm{N}_{2}$ and then $0.6 \mathrm{~mL}$ of extraction buffer was added to each sample. The extraction buffer contained $0.2 \mathrm{M}$ TRIS (hydroxymethyl)aminomethane ( $\mathrm{pH} 8.0$ ); 10\% glycerol; 0.25\% Triton X-100; $0.5 \mathrm{mM}$ phenylmethanesulfonyl fluoride (PMSF); $0.01 \mathrm{mM}$ leupeptin and $100 \mathrm{mM} \mathrm{K}$ phosphate buffer ( $\mathrm{pH} \mathrm{6.6).} \mathrm{The}$ homogenate was left on ice for $20 \mathrm{~min}$, then centrifuged (10 $\mathrm{min}$, $7000 \mathrm{~g}, 4{ }^{\circ} \mathrm{C}$ ) and the supernatant was decanted. The reaction mixture (total volume of $1 \mathrm{~mL}$ ) contained $0.15 \mathrm{~mL}$ of crude enzyme

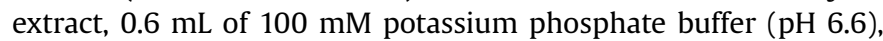
$50 \mathrm{U}$ of catalase, $50 \mu \mathrm{L}$ of 2 -aminobenzaldehyde ( $0.1 \%$ ) and $150 \mu \mathrm{L}$ of $20 \mathrm{mM}$ Put for DAO or $150 \mu \mathrm{L}$ of $20 \mathrm{mM}$ Spd for PAO measurements. The reaction was carried out at $37^{\circ} \mathrm{C}$ for $1.5 \mathrm{~h}$, and stopped with $50 \mu \mathrm{L}$ of $20 \%(\mathrm{w} / \mathrm{v})$ trichloroacetic acid (TCA) and the tubes were centrifuged at $5000 \mathrm{~g}$ for $10 \mathrm{~min}$. Formation of $\Delta^{1}$-pyrroline product was determined by reading the absorbance at $430 \mathrm{~nm}$ by spectrophotometer (KONTRON, Milano, Italy). Enzyme activity was expressed in nmol $\Delta^{1}$-pyrroline $\mathrm{min}^{-1} \mathrm{~g}^{-1} \mathrm{FW}$ using an extinction coefficient of $1.86 \times 10^{3} \mathrm{~mol}^{-1} \mathrm{~cm}^{-1}$.

\subsection{Determination of hydrogen peroxide $\left(\mathrm{H}_{2} \mathrm{O}_{2}\right)$ content}

$\mathrm{H}_{2} \mathrm{O}_{2}$ was measured by the method of Horváth et al. (2015). $200 \mathrm{mg}$ of leaf samples were homogenized in $0.5 \mathrm{~mL}$ of ice-cold, $0.1 \%$ TCA. Afterwards, the homogenate was centrifuged at $7000 \mathrm{~g}$ for $20 \mathrm{~min}$ at $4{ }^{\circ} \mathrm{C} .0 .25 \mathrm{~mL}$ of the supernatant was added to $0.25 \mathrm{~mL}$ of $50 \mathrm{mM}$ potassium phosphate buffer $(\mathrm{pH} 7.0)$ and $0.5 \mathrm{~mL}$ of $1 \mathrm{M}$ potassium iodide (KI). After $10 \mathrm{~min}$ incubation at $25^{\circ} \mathrm{C}$ the absorbance were recorded by spectrophotometer (KONTRON, Milano, Italy) at $390 \mathrm{~nm}$. The standard curve was prepared using $\mathrm{H}_{2} \mathrm{O}_{2}$ solution.

Table 1

Primer pairs used for qRT-PCR.

\begin{tabular}{|c|c|c|c|c|}
\hline Name of tomato gene & Abbreviations used in the article & Tomato genome locus identifier & & Primer pair sequences $\left(5^{\prime}-3^{\prime}\right)$ \\
\hline \multirow[t]{2}{*}{ Arginine decarboxylase } & SIADC & Solyc10g054440 & $\mathrm{F}:$ & GCCTTTTTCAGACCTTCAG \\
\hline & & & $\mathrm{R}$ : & TGCTCCGTATTTCACCGTTA \\
\hline \multirow[t]{2}{*}{ Ornithine decarboxylase } & SIODC & Solyc04g082030 & $\mathrm{F}:$ & TGACTCTTTTGCCGATGATG \\
\hline & & & $\mathrm{R}:$ & ACTTCCACGACTTCCCTGAG \\
\hline \multirow{2}{*}{ Spermidine synthase } & SISPDS & Solyc05g005710 & F: & CGACAGAAGAGTGACGGGATA \\
\hline & & & $\mathrm{R}:$ & GGTGCTGGTTATTGGAGGAG \\
\hline \multirow[t]{2}{*}{ Spermine synthase } & SISPMS & Solyc03g007240 & $\mathrm{F}:$ & GCAGCAAGGAAAAGAAATGG \\
\hline & & & $\mathrm{R}:$ & GCAGGGAGTGGAGTCAAGAT \\
\hline \multirow[t]{2}{*}{ Copper amine oxidase } & SIDAO1 & Solyc05g013440 & F: & AATACGGGTTCGGGTTACAA \\
\hline & & & $\mathrm{R}$ : & TGCCACAAATACACCATCCATA \\
\hline \multirow[t]{2}{*}{ Copper amine oxidase } & SIDAO2 & Solyc09g075940 & $\mathrm{F}:$ & GTCTGGAGTGGCAGGAATAGA \\
\hline & & & $\mathrm{R}:$ & CGGAGTTCAAAAGCATCATTG \\
\hline \multirow[t]{2}{*}{ Polyamine oxidase } & SIPAO1 & Solyc01g087590 & F: & CCGTCAАCTCCAAAAACACC \\
\hline & & & $\mathrm{R}:$ & TCСТCTTTCATCAGCAACCA \\
\hline \multirow[t]{2}{*}{ Polyamine oxidase } & SIPAO2 & Solyc07g039310 & $\mathrm{F}:$ & CGGAGTTCAAAAGCATCATTG \\
\hline & & & $\mathrm{R}:$ & CCAAAAGCCCATCCATACAC \\
\hline
\end{tabular}




\subsection{Detection of nitric oxide (NO) production}

NO production of tomato leaves was visualized using 4-amino5-methylamino-2', $7^{\prime}$-difluorofluorescein diacetate (DAF-FM DA) for $30 \mathrm{~min}$ in $10 \mathrm{mM}$ TRIS-HCl buffer (pH 7.4) in the dark at room temperature and rinsed twice with $10 \mathrm{mM}$ TRIS- $\mathrm{HCl}$ buffer (pH 5.8) (Poór et al., 2015). Leaflets were infiltrated with the dye under vacuum.

Fluorescence intensity was detected with Zeiss Axiowert 200Mtype fluorescence microscope (Carl Zeiss Inc., Jena, Germany) equipped with a high-resolution digital camera (Axiocam HR, Carl Zeiss Inc., Jena, Germany) and it was measured using filter set 10 (excitation 450-495 nm, emission 515-565 nm). Data were analyzed by AXIOVISION REL. 4.8 software (Carl Zeiss Inc., Munich, Germany).

\subsection{Statistical analysis}

Results are expressed as mean \pm SE. Data presented are average values from at least three independent experiments and in each treatment at least three independent samples were measured. Statistical analysis was carried out with Sigma plot 12.0 software (SPSS, Erkrath, Germany). The control and the two SA treatments under light and dark conditions were compared. After analysis of variance (ANOVA), Duncan's multiple comparisons were performed. Means were considered to be significantly different if $\mathrm{P} \leq 0.05$.

\section{Results}

\subsection{The stability and integrity of the plasma membrane after SA treatments}

Light is required in several physiological and developmental processes of plant life cycle. The first $24 \mathrm{~h}$ after SA treatments is particularly important because different concentrations of SA can induce acclimation such as $0.1 \mathrm{mM}$ SA (Szepesi et al., 2009) or cell death such as $1 \mathrm{mM} \mathrm{SA}$ (Poór et al., 2013) in tomato plants. To detect the effects of SA on membrane integrity and cell viability of leaf tissues, electrolyte leakage (EL) was measured as a function of time.
Exogenous application of $0.1 \mathrm{mM}$ SA did not lead to the loss of membrane integrity (Fig. 1B), but $1 \mathrm{mM} \mathrm{SA}$ induced an increase in EL after $24 \mathrm{~h}$, which was significantly higher under light than under dark conditions (Fig. 1C).

Another important injury indicator of plant cells under stress condition is the degree of lipid peroxidation, which was estimated as the amount of the thiobarbituric acid-reactive substances, mainly MDA. Lower SA concentration had no impact on leaf MDA content, but the product of lipid peroxidation was significantly increased in $1 \mathrm{mM}$ SA treated leaves after $6 \mathrm{~h}$. This change was significantly higher in the illuminated leaves than in the ones exposed to darkness. The results suggest that the stability and integrity of plasma membrane was significantly reduced in illuminated leaves after the treatment with $1 \mathrm{mM} \mathrm{SA}$ (Fig. 2).

\subsection{SA modulated light-dependent accumulation of free polyamines}

To examine the importance of light and dark conditions in PA metabolism, free PA contents were measured in the leaves of tomato plants after the different SA treatments. Under the light, the accumulation of PAs showed diurnal rhythm in the control leaves (Fig. 3A, D and G), leading to increased PA level in late afternoon. In contrast to this tendency in the light, the accumulation of Put and Spd occurred in the first hours in the dark environment. Treatment with $0.1 \mathrm{mM}$ SA decreased Put levels compared to the control in the light but increased it in the dark after $1 \mathrm{~h}$ (Fig. 3B). However, the accumulation of Spd was enhanced only slightly by $0.1 \mathrm{mM} \mathrm{SA}$ compared to the control both in dark and light environments (Fig. 3E). Spm content increased also in the presence of $0.1 \mathrm{mM} \mathrm{SA}$ compared to the control leaves (Fig. $3 \mathrm{H}$ ), but it was enhanced only under the dark condition in the first $6 \mathrm{~h}$ of the treatment. In contrast to $0.1 \mathrm{mM}$ SA treatment, $1 \mathrm{mM}$ SA caused pronounced increase in free Put, which was markedly higher under the dark condition after $12 \mathrm{~h}$ (Fig. 3C) than in the light. In addition, levels of Spd increased only by $1 \mathrm{mM}$ SA treatment after $12 \mathrm{~h}$ in darkness (Fig. 3F). The most characteristic changes were observed in the Spm levels of the $1 \mathrm{mM}$ SA treated leaves. Spm concentrations fluctuated more frequently than in any other cases in leaf tissues and the maximum values were detected earlier in those plants which had

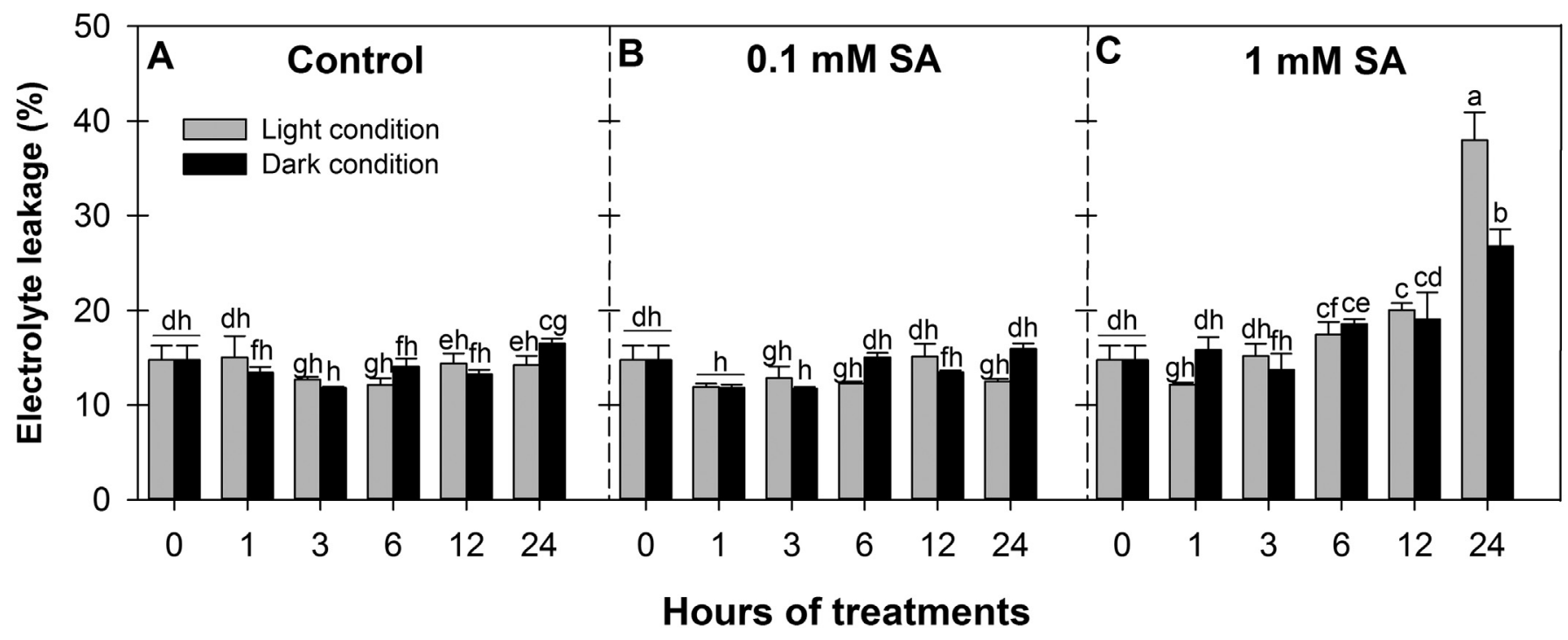

Fig. 1. Changes in the electrolyte leakage (EL) from the leaves of control plants (A) or plants exposed to $0.1 \mathrm{mM}(\mathrm{B})$ or $1 \mathrm{mM}$ SA (C) in the presence or absence of light ( $\square$ Light,

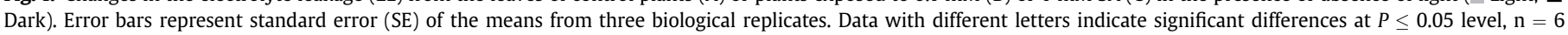
(Duncan's multiple range test) in each time point. 


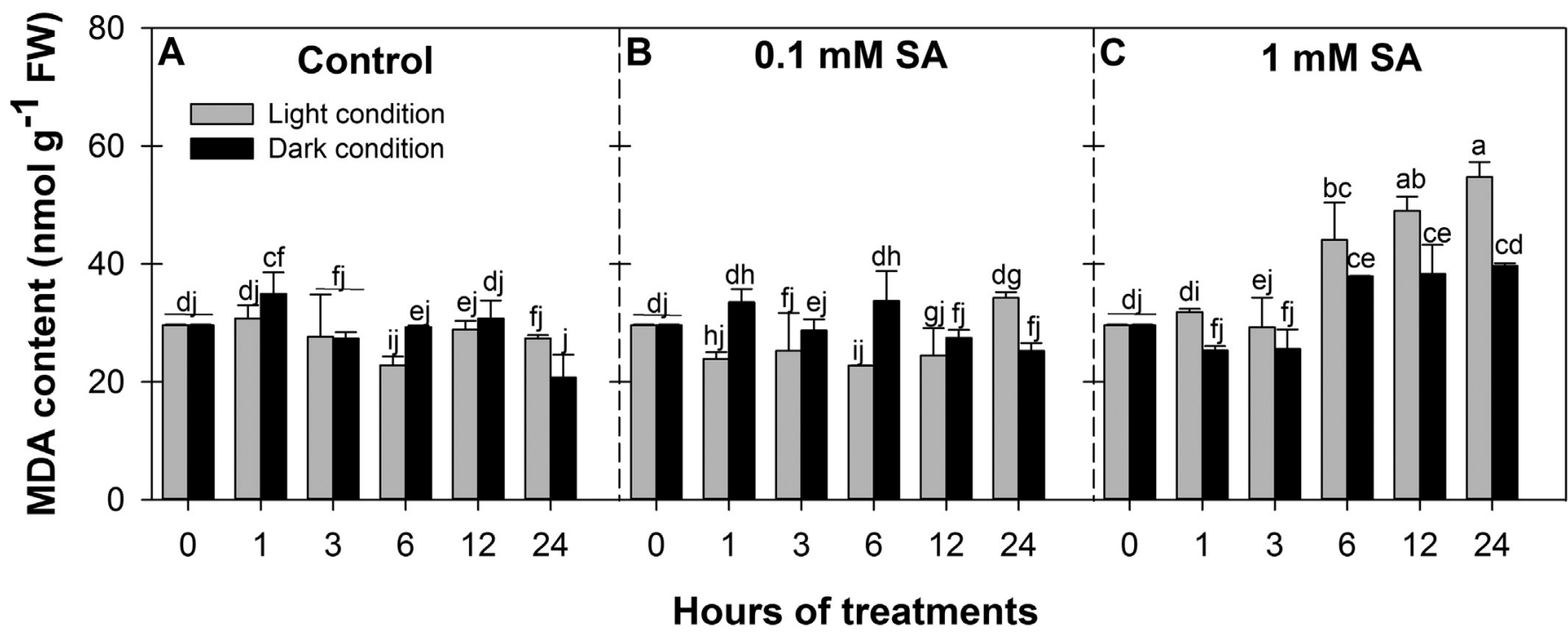

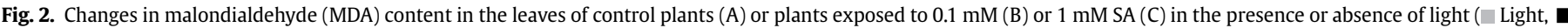

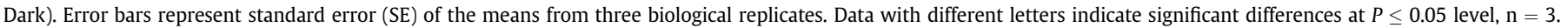

been put into darkness (Fig. 3I). In summary, PA contents were markedly different under the light and the dark conditions after treatment with $1 \mathrm{mM}$ SA. Put and Spm accumulation showed pronounced increase in the dark, while Spm content was also enhanced in the light after $24 \mathrm{~h}$, which suggests the different function of SA-induced PAs in the SA-mediated reactions under light or dark conditions.

Besides the measurements of free PA contents, SA-induced expression of PA biosynthesis genes was also analyzed. The relative expression levels of tomato SIADC and SIODC genes did not change significantly during the experiments in control leaves and displayed weak expression in the dark (Fig. 4A and D). Similar tendencies were shown in case of the expression pattern of SISPDS, but this gene was activated in the late afternoon in illuminated leaves of control plants (Fig. 4G). However, changes in the expression of tomato SISPMS were not significant under the investigated environmental circumstances (Fig. 4J). Treatment with $0.1 \mathrm{mM} \mathrm{SA}$ induced the expression of SIADC compared to the control, which was initiated earlier and better in darkness compared to the illuminated plants (Fig. 4B), however, the expression of SIODC did not change in case of $0.1 \mathrm{mM}$ SA treatment (Fig. 4E). At the same time, relative expression of SISPDS was induced by $0.1 \mathrm{mM}$ SA after $3 \mathrm{~h}$ compared to the control, but there was no difference between the light or dark treated samples (Fig. 4H). The expression of SISPMS was induced in the leaves of $0.1 \mathrm{mM}$ SA treated plants after 1 and $3 \mathrm{~h}$ under the dark, but it did not change under the light (Fig. 4K). It can be concluded that $0.1 \mathrm{mM}$ SA induced the expression of SIADC and SISPMS genes more efficiently in the dark than in the light. Unlike lower SA concentration, 1 mM SA caused significantly higher expression of SIADC and SIODC genes after 3 and $6 \mathrm{~h}$, respectively in the light (Fig. 4C and F). In contrast to the early responses, these maxima can be observed later in the dark than in the light. Relative expression of SISPDS was also induced by $1 \mathrm{mM}$ SA after 6 and $24 \mathrm{~h}$ in the light but it was blunted in the dark (Fig. 4I). 1 mM SA caused significantly high and early expression of SISPMS in the dark after $3 \mathrm{~h}$, but later it fluctuated, and the expression level of the gene was significantly higher after $24 \mathrm{~h}$ in the light (Fig. 4L).

\subsection{SA-induced polyamine catabolism}

To detect the light-dependency of SA-induced PA catabolism,
DAO and PAO activities were investigated. The activity of DAO decreased in the morning and it increased in the afternoon in the normal light, but the decline was more pronounced in the dark (Fig. 5A). $0.1 \mathrm{mM}$ SA induced DAO activity after $3 \mathrm{~h}$, which was significantly higher in the dark (Fig. 5B). At the same time point, DAO activity was inhibited and remained at constant level in the presence of $1 \mathrm{mM}$ SA in illuminated samples (Fig. 5C). However, $1 \mathrm{mM}$ SA induced DAO activity in the dark after 1 and $24 \mathrm{~h}$ compared to the control (Fig. 5C).

Similar tendencies can be found in the expression levels of the genes encoding DAOs, SIDAO1 and SIDAO2, which exhibited a constant low expression in control leaves in the light but were inhibited in the dark (Fig. 6A and D). Early and significant upregulation of SIDAO1 and SIDAO2 was detected in the leaves of $0.1 \mathrm{mM}$ SA-treated plants under the dark after $3 \mathrm{~h}$, but both of the genes were up-regulated later in the light (Fig. 6B and E). However, in the presence of $1 \mathrm{mM} \mathrm{SA}$ the expression of DAOs was much lower and increased only in the dark (Fig. $6 \mathrm{C}$ and F).

The specific activity of PAO was enhanced in the afternoon in the control plants under normal photoperiod in illuminated leaves. However, dark treatment delayed this increment in enzyme activity (Fig. 7A). SA induced very similar increases in the PAO activity after $3 \mathrm{~h}$ in the light at both concentrations (Fig. 7B) but the enzyme activity exhibited more pronounced fluctuations with two maxima in plants exposed to $1 \mathrm{mM}$ SA both in dark and light conditions (Fig. 7C).

SA can regulate the tomato PAOs, SIPAO1 and SIPAO2 at transcriptional level. It has to be mentioned that SA treatment had higher impact on SIPAO1, especially in case of $0.1 \mathrm{mM}$ and SA elicited strong fluctuation in its expression with an early maximum in the light and a late maximum in the dark (Fig. 8B and C). The expression of SIPAO2 decreased in the afternoon in the illuminated control leaves and this decline was more pronounced in the dark (Fig. 8A and D). Nevertheless, there were only small increases in the expression of SIPAO2 after SA treatments which was dampened at higher SA concentration (Fig. 8E and F).

\section{4. $\mathrm{SA}$ generated light-dependent $\mathrm{H}_{2} \mathrm{O}_{2}$ and $\mathrm{NO}$ production}

$\mathrm{H}_{2} \mathrm{O}_{2}$ and $\mathrm{NO}$ are important signalling components in SA induced physiological responses, which can be produced also by PA 


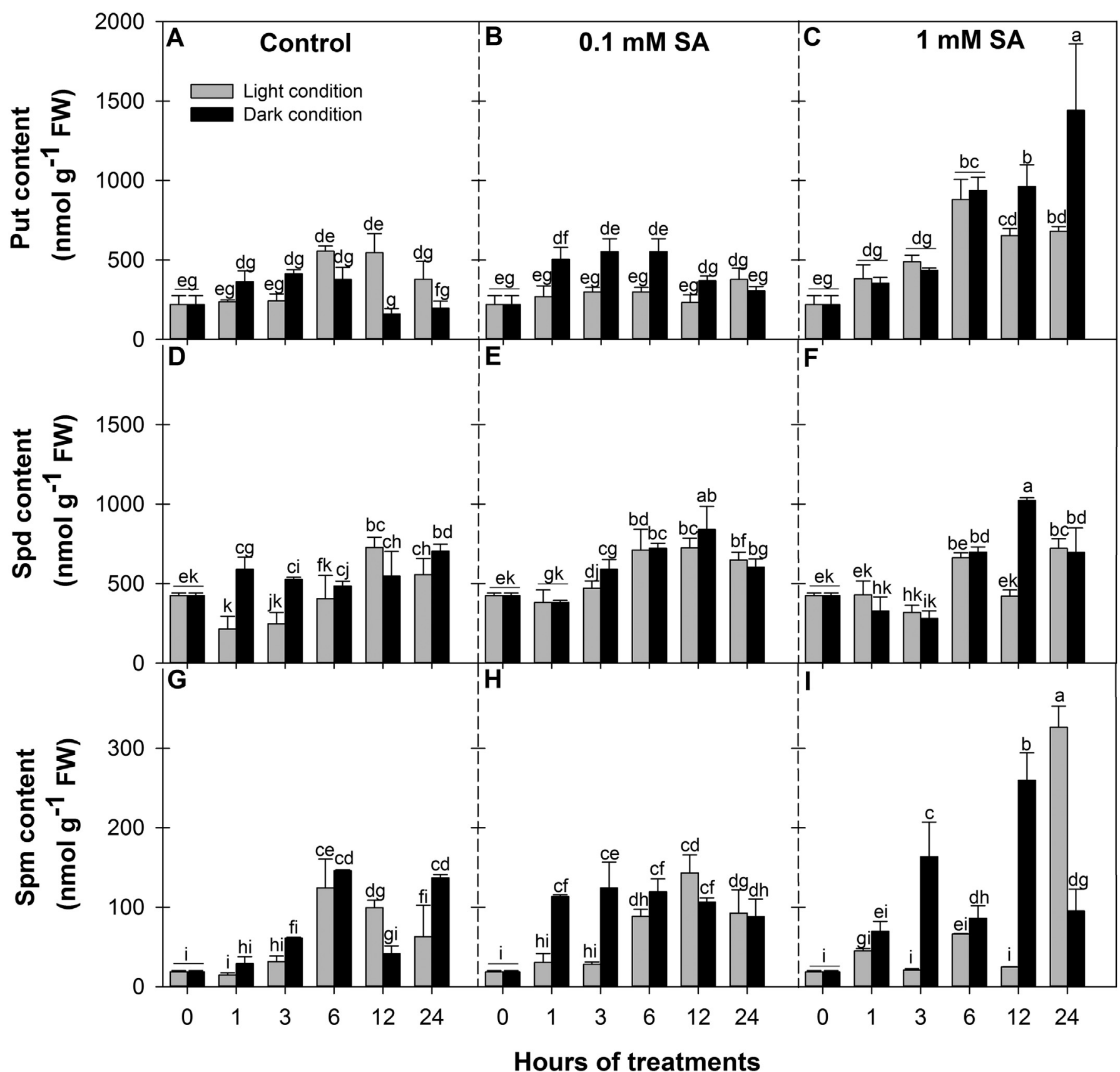

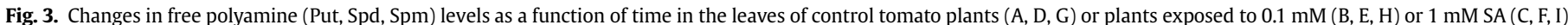

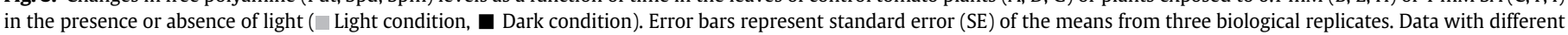
letters indicate significant differences at $P \leq 0.05$ level, $\mathrm{n}=3$.

catabolism and regulated by light. $\mathrm{H}_{2} \mathrm{O}_{2}$ content did not change markedly in the control samples after $1 \mathrm{~h}$ (Fig. 9A). $0.1 \mathrm{mM}$ SA caused time-dependent increase in $\mathrm{H}_{2} \mathrm{O}_{2}$ levels, which was significantly lower in the dark (Fig. 9B). $\mathrm{H}_{2} \mathrm{O}_{2}$ contents in the leaves exposed to $1 \mathrm{mM}$ SA showed the same tendencies but the changes were higher and more rapid in the light, while $\mathrm{H}_{2} \mathrm{O}_{2}$ increased only after 6,12 and $24 \mathrm{~h}$ in the darkness (Fig. 9C).

NO production exhibited a small decline during the day in the control leaves and in the leaves treated with $0.1 \mathrm{mM}$ SA in both environments (Fig. 10A and B). In contrast, $1 \mathrm{mM}$ SA induced significant NO production after the 6th $\mathrm{h}$ compared to the control in illuminated leaves, but NO level declined under the dark (Fig. 10C).

\section{Discussion}

Two different concentrations of SA ( $0.1 \mathrm{mM}$ or $1 \mathrm{mM})$ were tested under light or dark conditions in the first $24 \mathrm{~h}$ of the treatments. This time period after SA treatments is particularly important because it can determine the acclimation processes of the whole plant. Van den Burg and Takken (2009) reported that SA accumulation and transcriptional regulation of SA-responsive loci were rapidly induced after pathogen recognition and they distinguished an early (0-6 h) and a late (6-24 h) phases in the transcriptional regulation and chromatin modification. Thus, the lack of light can be crucial in this early time period. Liu et al. (2011) also revealed that development of SA-induced SAR was determined by 


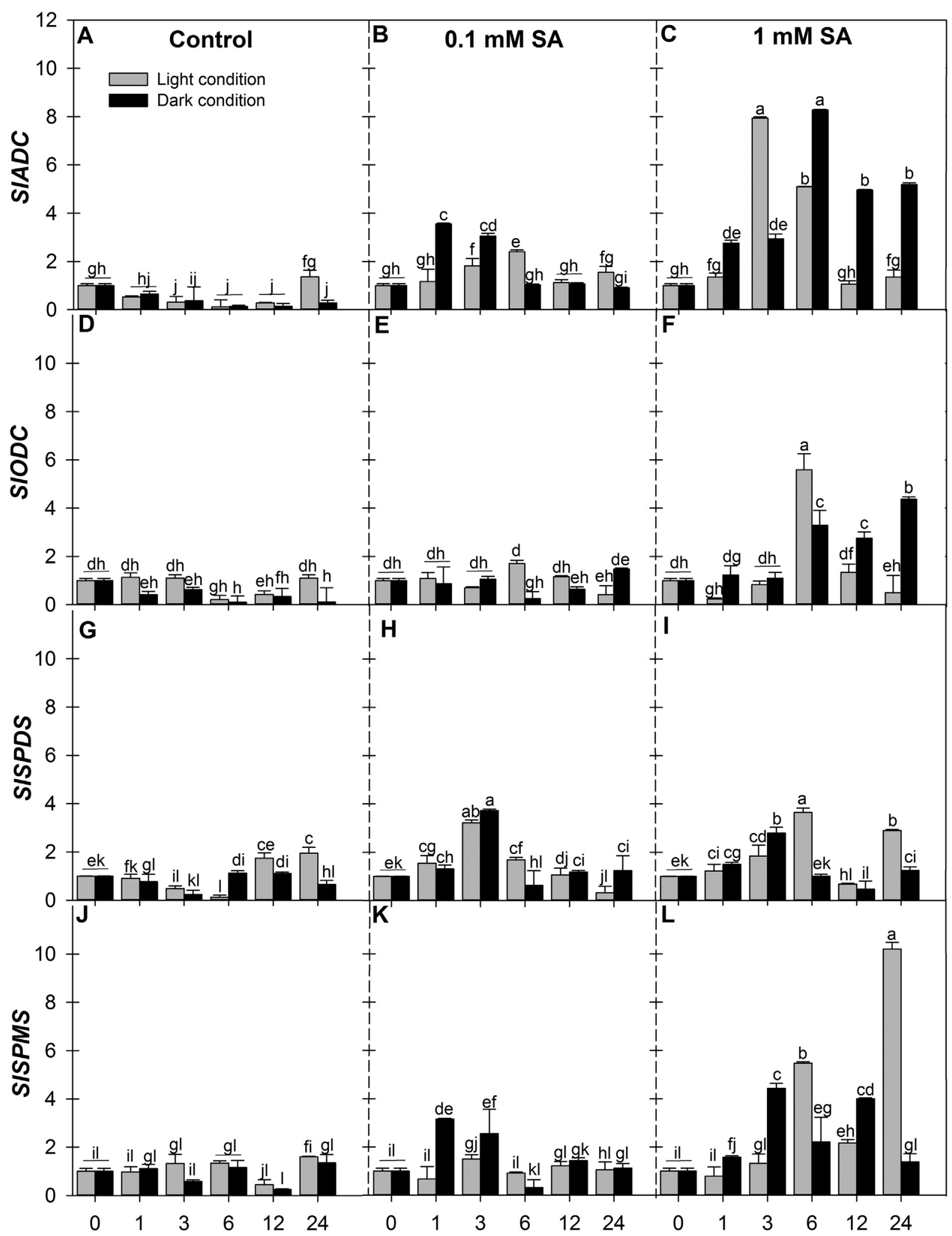

Hours of treatments

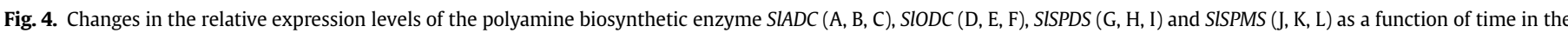

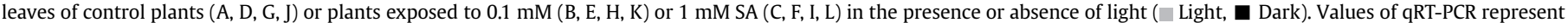
means \pm SE of three independent experiments.

the beginning of infection: two pathways work synergistically to induce SAR, one is light dependent and the other is not.
Maintenance of the integrity of cellular membranes under stress is considered an integral part of tolerance mechanisms. Electrolyte 


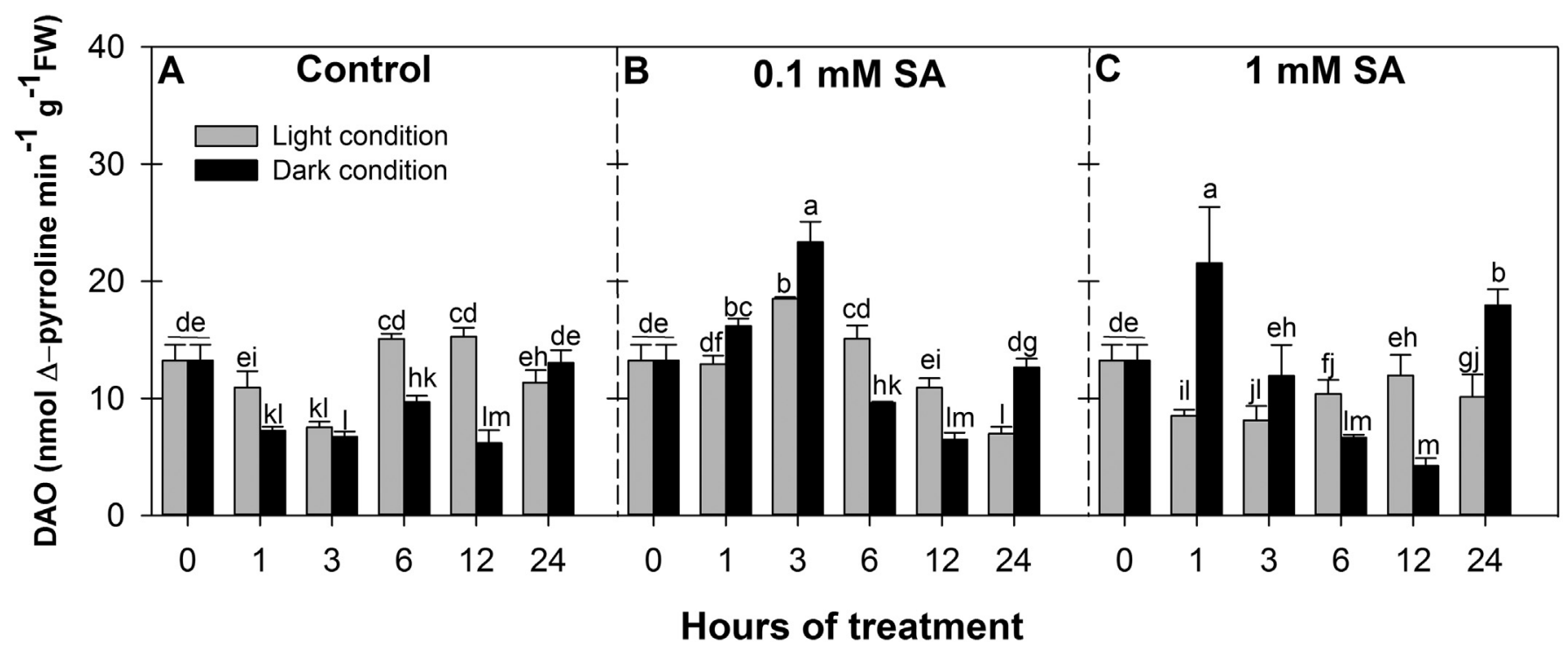

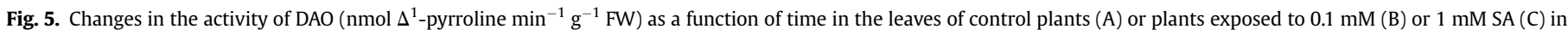

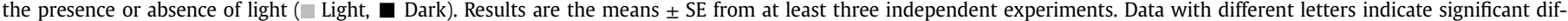
ferences at $P \leq 0.05$ level, $\mathrm{n}=3$.

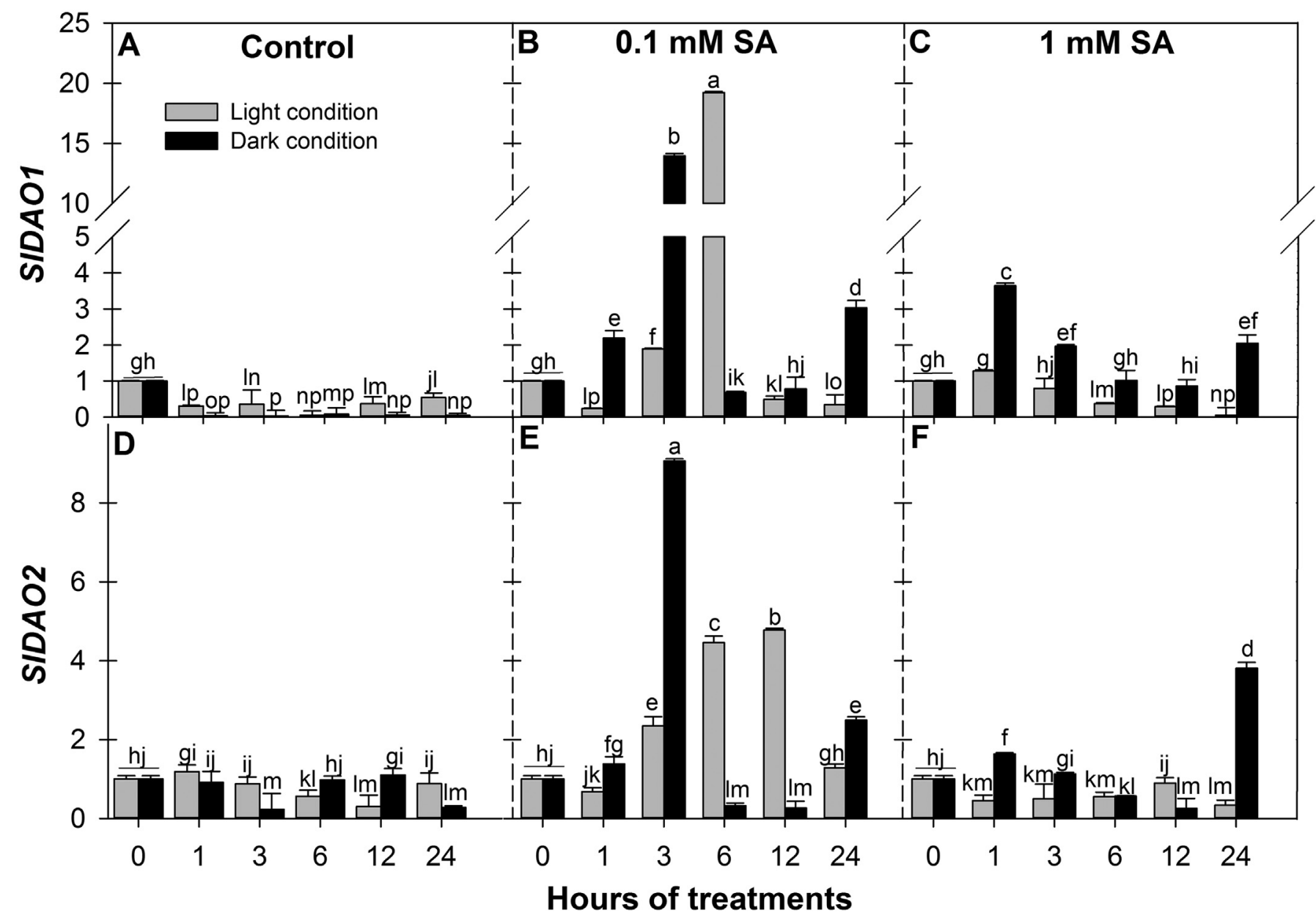

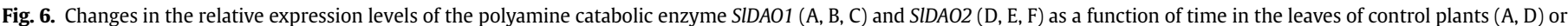

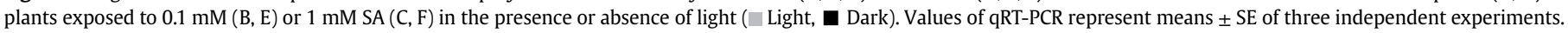

leakage, which is a characteristic feature of cell death induction, was increased only by higher, 1 mM SA concentration to irreversible level (about 40\%) after 24 h both in the light and dark (Poór et al., 2013), but the effect was much pronounced in illuminated leaves. 


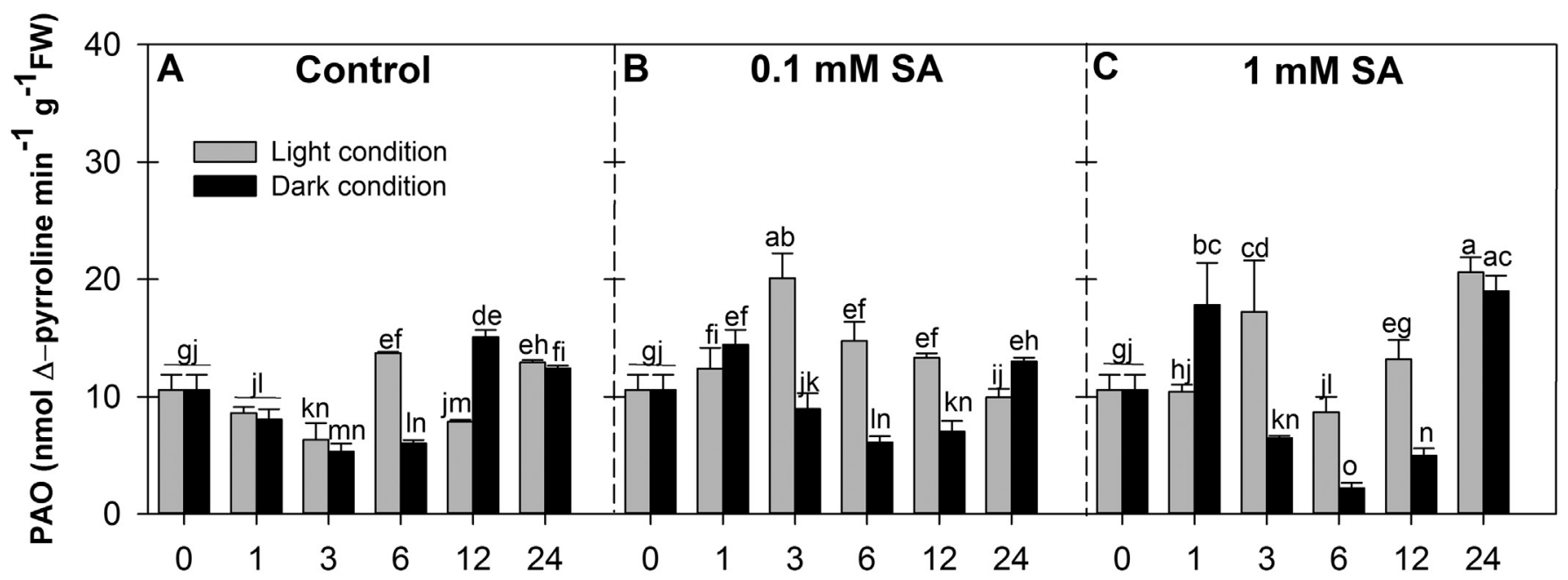

Hours of treatment

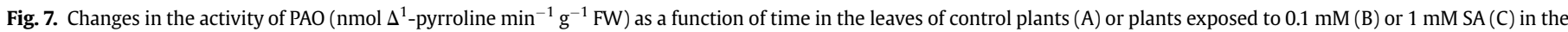

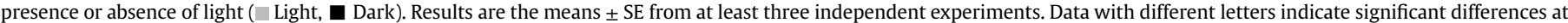
$P \leq 0.05$ level, $\mathrm{n}=3$.

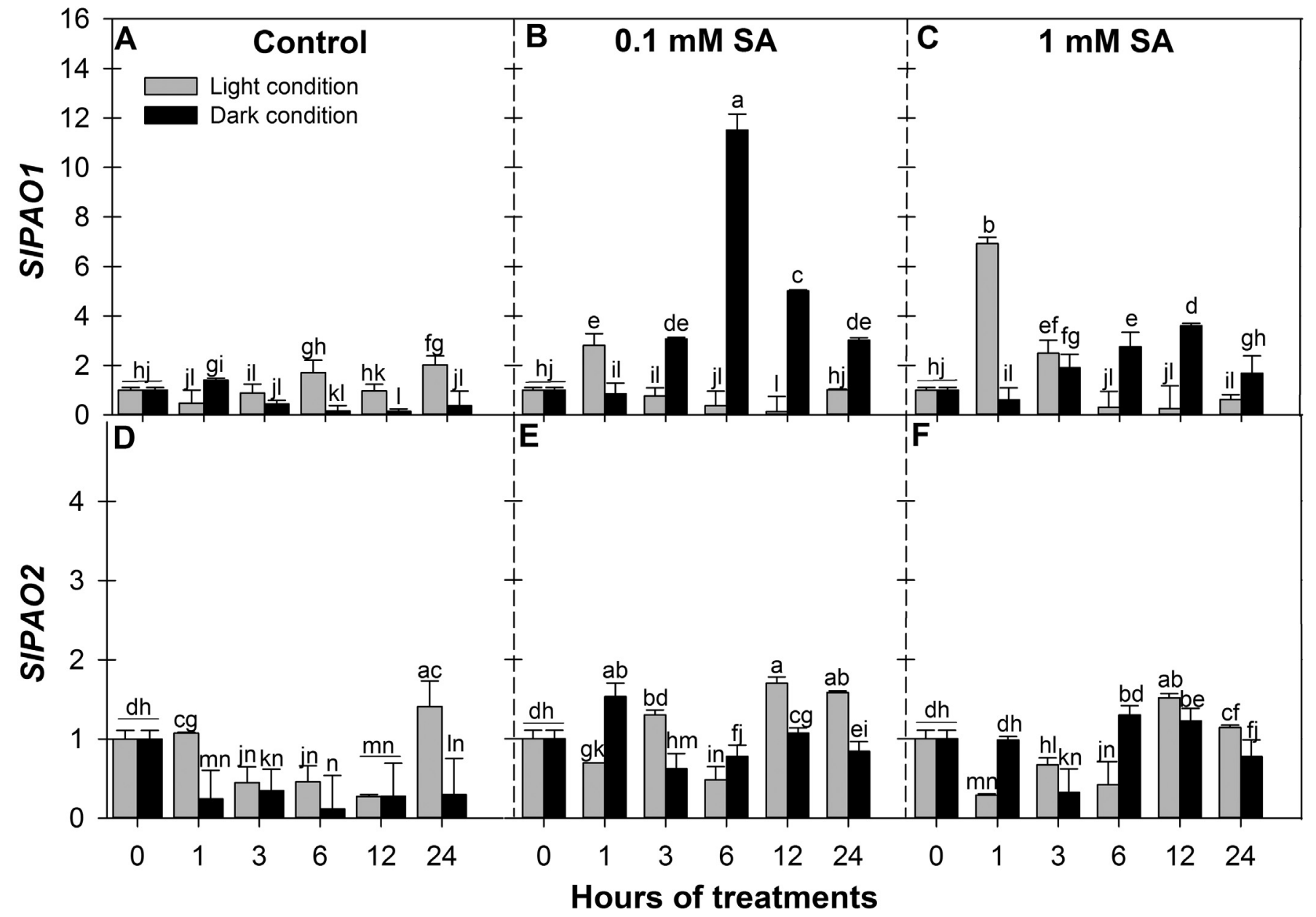

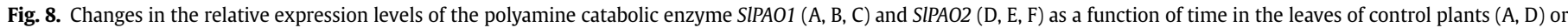

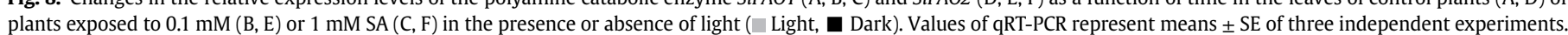

Loss of membrane integrity exhibited strong correlation with the enhanced lipid peroxidation, which is used also as an indicator of oxidative damage. $1 \mathrm{mM}$ SA increased MDA accumulation significantly in illuminated leaves, but in the dark lipid peroxidation 


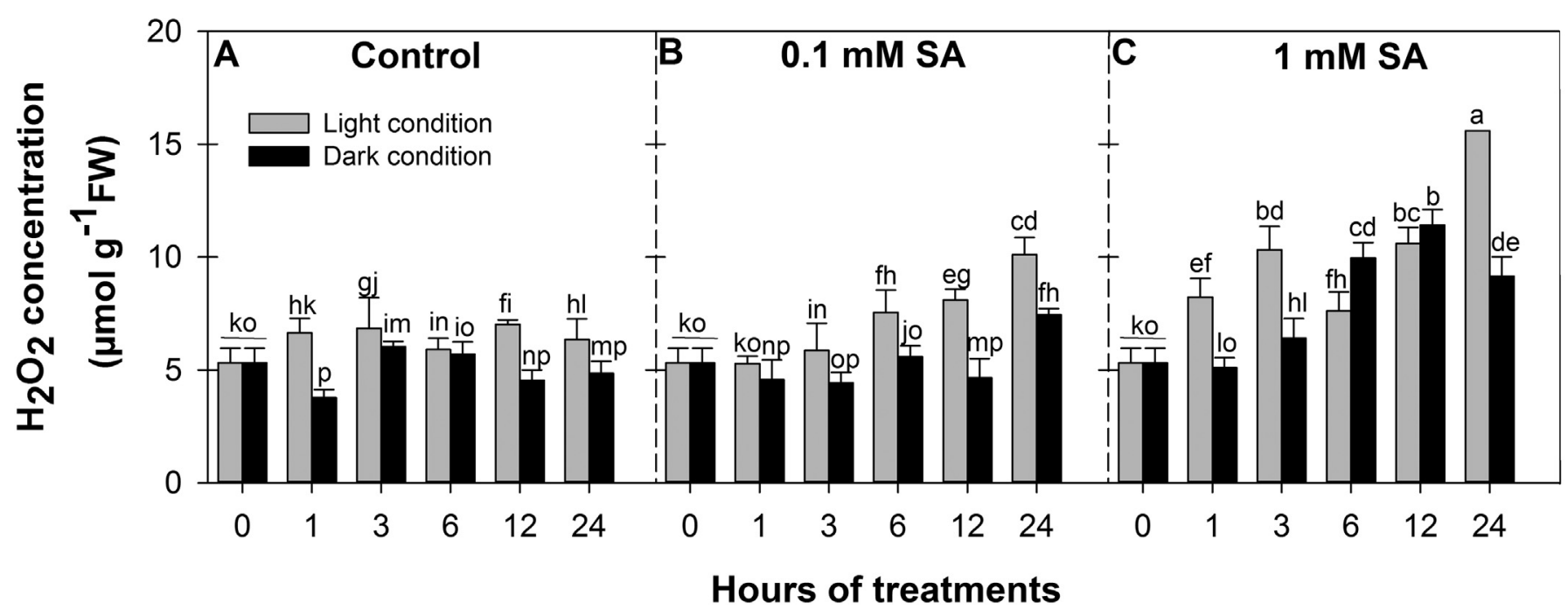

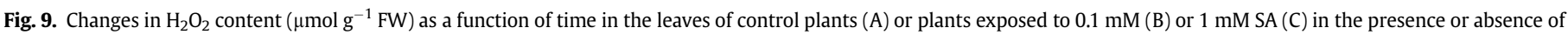

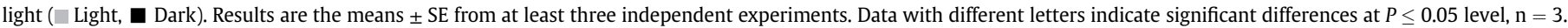

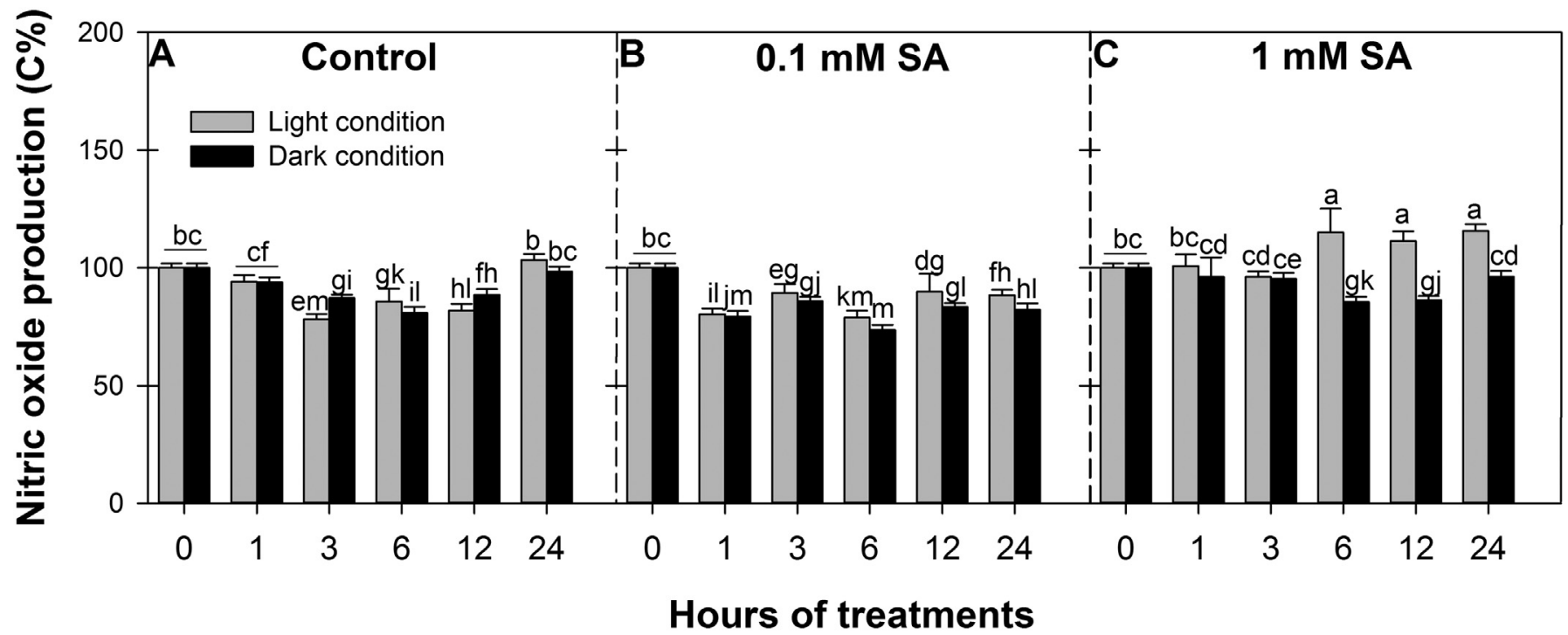

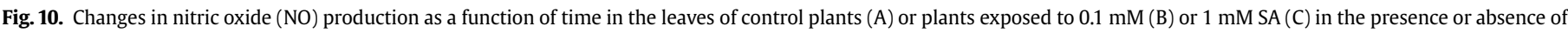

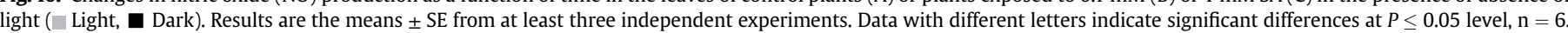

proved to be smaller. These results demonstrated that SA has a concentration- and light dependent effect on membrane integrity and cell death induction.

Changes in PA content in the leaves of tomato showed diurnal rhythm, the maximum of free PAs and the activation of $A D C$ and $O D C$ were in the middle of the light cycle, which was also described by Gemperlová et al. (2006) in the leaves of tobacco plants. Similar tendencies were found in our experiments, in the light, Put, Spd and Spm contents exhibited maxima between 6 and 12, at $12 \mathrm{~h}$ and at 6 h, respectively. However, in plants kept in darkness Put and Spd accumulation appeared earlier. Some diurnal fluctuation remained in leaves treated with $0.1 \mathrm{mM}$ SA, and the maxima of Put and Spm accumulation could be detected earlier, from the 1-h sample in the dark. Diurnal cycles of PAs show much higher and more frequent fluctuations in the illuminated leaves after $1 \mathrm{mM}$ SA treatment, which has been diminished in the dark in the case of Put. PA levels in plant tissues are under strict control because not only PA depletion but also extensive PA accumulation may be deleterious (Jiménez-Bremont et al., 2014). Relative to Put and Spd, the cellular Spm content is often small. This may reflect the necessity of plant cells to maintain Spm below a certain threshold concentration. A very significant accumulation of Put and Spm but not that of Spd can be observed in the leaves of plants exposed to higher concentration of SA especially in darkness, which suggests that PAs in this case can contribute to the maintenance of membrane integrity, thus to the late induction of cell death in the leaves kept under dark condition.

Yaakoubi et al. (2014) revealed a protective action of Spm and Spd on the stability of the isolated thylakoid membranes subjected to photoinhibition and these PAs were also effective in PSI photostability. Thus, increased Spm content in the leaves of SA-treated plants under light conditions can scavenge superoxide radicals in the thylakoids. Similarly, at lower SA concentration, Spm improved the photosynthetic functions under stress (Serafini-Fracassini et al., 
2010). In the dark, $1 \mathrm{mM} \mathrm{SA}$ induced early and high accumulation of Spm and later the accumulation of Put, which were the most characteristic differences between the dark and light environments. We suppose that this early increase in PAs contribute to the delayed cell death initiation in these tissues.

PA homeostasis can be achieved by transcriptional and translational regulation of enzymes, $\mathrm{ADC}$ and $\mathrm{ODC}$, by regulation of catabolic enzymes, DAOs and PAOs, by conjugation of free PAs with phenolic compounds and sequestration of PAs to apoplast or vacuoles. Moreover, PAs synthesized in the roots can be transported to shoot via xylem, by the activity of L-type amino acid transporter (LAT) family transmembrane proteins found in the xylem parenchyma cells (Fujita and Shinozaki, 2015). In our experiments Put accumulation correlated well with the expression of the genes encoding PA biosynthetic enzymes, SIADC and SIODC. In control plants the expression of these genes was low, at some points of time they were higher in the light than in the dark, and showed diurnal fluctuation. Similar tendencies were found in the case of SISPDS and SISPMS genes. It can be concluded that much higher induction occurred after lethal SA treatment in SIADC, SIODC and SISPMS expression than after sublethal one, but the expression of SISPDS has not been changed significantly with increasing SA concentrations. The relative importance of ADC and ODC activities in Put biosynthesis was different at low and high SA because $O D C$ gene has not been induced by $0.1 \mathrm{mM}$ SA. However, it was highly upregulated by high concentration suggesting that $A D C$ is more important in Put biosynthesis during stress acclimation than ODC. $A D C$ expression displays a good correlation with Put content in the dark, and the maximum expression precedes Put accumulation at low SA treatment. Thus it can be concluded that PA biosynthesis exerts a significant control over PA level in the first $24 \mathrm{~h}$ of SA treatment.

ROS can be generated by various processes and cellular compartments and PAs may act as antioxidants or prooxidants. It was earlier found that exogenous PAs reduced the level of $\mathrm{H}_{2} \mathrm{O}_{2}$ and MDA by activating enzymatic and non-enzymatic antioxidants ( $\mathrm{Li}$ et al., 2015). However, the terminal oxidation of PAs by apoplastic DAO and PAO isoenzymes released $\mathrm{H}_{2} \mathrm{O}_{2}$ as final product in the cell wall, which can contribute to the second phase of the oxidative burst and induces cell death both in biotic (Yoda et al., 2003, 2006) and abiotic stress (Moschou et al., 2012). Gemperlová et al. (2006) found that DAO activity changed together with the content of free Put. In our experiments, DAO expression and activity did not show strict correlation with Put content, suggesting a more complex control mechanism in this system. Based on the results, $0.1 \mathrm{mM} \mathrm{SA}$ induced DAO activity and the expression of SIDAO1 and SIDAO2 both in the light and dark, nevertheless $1 \mathrm{mM}$ SA caused much lower induction and significant changes occurred only in the dark and not in the light. Generally, the expression of genes encoding DAO isoenzymes was higher in the dark than in the light. It can be concluded that treatment with $1 \mathrm{mM}$ SA induced the biosynthesis and catabolism of Put much effectively in the dark. However, it did not induce the Put catabolism in illuminated leaves. These two processes exhibit a loose relationship, higher DAO activity may control Put level at lower SA concentration, while the accumulation of free Put at higher SA is controlled mostly by biosynthesis which is modulated by the degradation or by other processes, such as conjugation or back conversion. In control plants the expression of SIPAO2 exhibited a diurnal fluctuation which was more intensive in the light. The activity of PAO and the relative expression levels of the PA catabolic enzymes encoding SIPAO1 and SIPAO2 were enhanced by both SA treatments in both environments. The expression of SIPAO1 at both SA concentrations was significantly higher in the dark after $6 \mathrm{~h}$ than in control plants but this was not correlated with the terminal oxidation of higher PAs.
The levels of $\mathrm{H}_{2} \mathrm{O}_{2}$ increased as a function of time at both SA concentrations but much steeper at the higher SA in the light, which was dampened under the dark condition. Moreover, we did not find temporal coincidence between $\mathrm{H}_{2} \mathrm{O}_{2}$ accumulation and PA catabolism. This means that ROS production by photosynthesis at $1 \mathrm{mM}$ SA can overrun ROS generated by terminal oxidation of PAs in actively photosynthesizing tissues. It is in accordance with our earlier results, where we found that, SA inhibited photosynthesis and led to photoinhibition in tomato leaves (Poór et al., 2011) only at cell death inducing concentrations.

These important differences in SA mediated responses in the light and in the dark imply crucial roles of chloroplasts. Lightinduced ROS may arise in different cellular compartments. NADPH oxidases which mediates the progression of ROS signals from cell to cell, generates superoxide and $\mathrm{H}_{2} \mathrm{O}_{2}$ in the apoplast. DAOs and PAOs with cell wall localization may contribute to apoplastic ROS in light-dependent manner. Chloroplasts under high light are positioned to the plasma membrane, which ensures the diffusion of apoplastic $\mathrm{H}_{2} \mathrm{O}_{2}$ to chloroplasts and thus the interplay between apoplastic and chloroplastic ROS signals (Karpiński et al., 2013). Chloroplasts may also communicate with other intracellular compartments participating in ROS generations, such as mitochondria or peroxisomes and the cytoplasm, where several DAO and PAO isoenzymes are localized, thus PA oxidation and back conversion may modulate ROS production and ROS signals in a variety of ways (Saha et al., 2015).

SA treatments induced not only $\mathrm{H}_{2} \mathrm{O}_{2}$ accumulation but also the production of NO in a light dependent manner. Unexpectedly, NO accumulation displayed a small decline during the day in control plants and after $0.1 \mathrm{mM}$ SA treatment and there was no significant difference between light and dark samples. However, at high SA concentration, which induced small, HR-like lesions in the leaves, NO accumulated above the control level from $6 \mathrm{~h}$ in the light. At the same time, its level declined significantly in the leaf tissues in the dark. These results suggest that high SA concentration effectively induced $\mathrm{H}_{2} \mathrm{O}_{2}$ and $\mathrm{NO}$ accumulation eliciting simultaneous oxidative and nitrosative stress and concomitant cell death in the illuminated leaves. This is reflected by the loss of membrane integrity and enhanced lipid peroxidation. In the dark, leaf tissues produced less $\mathrm{H}_{2} \mathrm{O}_{2}$, and $\mathrm{NO}$ content remained below the control level, the tissues were exposed to smaller stress than in the light, which slowed down the initiation of cell death program.

Higher plants possess different sources and enzymes for NO production than animals, among which one of the most important sources is nitrate reductase (NR) (Dean and Harper, 1988). In plant tissues NR is inactivated by posttranslational phosphorylation and binding of 14-3-3 proteins in the presence PAs. Similarly, the activity of NR was reduced in the dark, which led to decreased generation of NO. NO emission from leaves of Nicotiana plumbaginifolia was also higher when this posttranslational regulation of NR was abolished (Lillo et al., 2004). Since PA accumulation is obviously higher in the leaves under dark condition than in the light at $1 \mathrm{mM}$ SA, blunted NO accumulation can be associated with decreased NR activity. NO bioactivity can modulate cellular signalling through Snitrosylation of target proteins by adding NO moiety to specific cysteines, which leads to the generation of S-nitrosothiols. In recent article Yun et al. (2016) found that endogenous NO accumulation in Arabidopsis NO OVEREXPRESSION 1 (nox1) mutants led to disabled Resistance $(R)$ gene-mediated basal resistance and defence against non-adapted pathogens which was a consequence of reduced SA signalling. The target of NO for S-nitrosylation in SA signalling is NPR1, a transcriptional co-activator of SA-dependent genes, which promotes NPR1 oligomer formation, leading to sequestration of NPR1 in the cytoplasm and to reduction in SA-induced gene expression (Tada et al., 2008). Thus, high concentrations of SA may 
induce oxidative- and nitrosative stress instead of defence reactions, which initiates cell death in illuminated leaf tissues.

\section{Conclusion}

It can be concluded that the different concentrations of SA induced distinct changes in PA metabolism, which were lightdependent and determined the outcome of SA-induced physiological response in a complex way. Biosynthetic genes, SIADC, SIODC and SISPMS were expressed to higher extent at lethal than at sublethal SA but PA catabolism by DAO and PAO was induced earlier and more intensively at sublethal concentration. These changes led to the accumulation of Put and Spm on the effect of $1 \mathrm{mM} \mathrm{SA}$, especially in the dark. Although PA oxidation contributed to ROS production, the most characteristic difference of SA effect between leaves kept in light or dark is that the high concentration of SA resulted in simultaneous accumulation of $\mathrm{H}_{2} \mathrm{O}_{2}$ and NO only in illuminated leaves. However, $\mathrm{NO}$ accumulation was not detected in the leaves exposed to $0.1 \mathrm{mM}$ or $1 \mathrm{mM}$ SA in darkness. We suppose that SA-induced PA catabolism and PA-catabolism-induced $\mathrm{H}_{2} \mathrm{O}_{2}$ contribute to defence reactions at sublethal SA concentration, while lethal concentration of SA generates substantial ROS production from other sources than terminal PA oxidation and induces simultaneous NO increase in the light, which can induce cell death.

\section{Contributions}

ZT, PP and IT designed the experiments, analyzed the data and wrote the manuscript. The experiments were conducted and figures were prepared by ZT.

\section{Acknowledgments}

This work was supported by grants from the Hungarian National Scientific Research Foundation (OTKA K101243 and OTKA PD112855). No conflict of interest is declared. This research was also supported by the European Union financing the HUSRB/120/ 221/173 PLANTTRAIN IPA Fund. We thank Etelka Kozma Bécs for her excellent technical assistance.

\section{References}

Bechtold, U., Karpinski, S., Mullineaux, P.M., 2005. The influence of the light environment and photosynthesis on oxidative signalling responses in plant-biotrophic pathogen interactions. Plant Cell Environ. 28, 1046-1055.

Belda-Palazón, B., Ruiz, L., Martí, E., Tárraga, S., Tiburcio, A.F., Culiáñez, F., Farràs, P., Carrasco, P., Ferrando, A., 2012. Aminopropyltransferases involved in polyamine biosynthesis localize preferentially in the nucleus of plant cells. PLoS One 7, e46907. http://dx.doi.org/10.1371/journal.pone.0046907.

Borlotti, C., Cordeiro, A., Alcázar, R., Borrell, A., Culiañez-Macià, F.A., Tiburcio, F.A. Altabella, T., 2004. Localization of arginine decarboxylase in tobacco plants. Physiol. Plant 120, 84-92.

Borrel, A., Carbonell, L., Farras, R., Puig-Parellada, P., Tiburcio, A.F., 1997. Polyamines inhibit lipid peroxidation in senescing oat leaves. Physiol. Plant 99, 385-390.

Caarls, L., Pieterse, C.M., Van Wees, S.C.M., 2015. How salicylic acid takes transcriptional control over jasmonic acid signaling. Front. Plant. Sci. 6, 170.

Cervelli, M., Tavladoraki, P., Di Agostino, S., Angelini, R., Federico, R., Mariottini, P., 2000. Isolation and characterization of three polyamine oxidase genes from Zea mays. Plant Physiol. Biochem. 38, 667-677.

Chandra-Shekara, A.C., Gupte, M., Navarre, D., Raina, S., Raina, R., Klessig, D. Kachroo, P., 2006. Light-dependent hypersensitive response and resistance signaling against Turnip Crincle virus in Arabidopsis. Plant J. 45, 320-334.

Cowley, T., Walters, D.R., 2002. Polyamine metabolism in barley reacting hypersensitively to the powdery mildew fungus Blumeria graminis f. sp. hordei. Plant Cell Environ. 25, 461-468.

Dean, J.V., Harper, J.E., 1988. The conversion of nitrite to nitrogen oxide(s) by the constitutive NAD(P)H-nitrate reductase enzyme from soybean. Plant Physiol. 88, 389-395.

Fujita, M., Shinozaki, K., 2015. Polyamine transport systems in plants. In: Kusano, T. Suzuki, H. (Eds.), Polyamines. Springer, Japan, pp. 179-185.

Gemperlová, L., Nováková, M., Vaňková, R., Eder, J., Cvikrová, M., 2006. Diurnal changes in polyamine content, arginine and ornithine decarboxylase, and diamine oxidase in tobacco leaves. J. Exp. Bot. 57, 1413-1421.

Genoud, T., Buchala, A.J., Chua, N.H., Métraux, J.P., 2002. Phytochrome signalling modulates the SA-perceptive pathway in Arabidopsis. Plant J. 31, 87-95.

Gémes, K., Poór, P., Horváth, E., Kolbert, Zs., Szopkó, D., Szepesi, Á., Tari, I., 2011. Cross-talk between salicylic acid and $\mathrm{NaCl}$-generated reactive oxigen species and nitric oxide in tomato during acclimation to high salinity. Physiol. Plant $142,179-192$.

Gilbert, G.S., Reynolds, D.R., 2005. Nocturnal fungi: airborne spores in the canopy and understory of a tropical rain forest 1 . Biotropica $37,462-464$.

Hayat, Q., Hayat, S., Irfan, S.M., Ahmad, A., 2010. Effect of exogenous salicylic acid under changing environment: a review. Environ. Exp. Bot. 68, 14-25.

Horváth, E., Csiszár, J., Gallé, Á., Poór, P., Szepesi, Á., Tari, I., 2015. Hardening with salicylic acid induces concentration-dependent changes in abscisic acid biosynthesis of tomato under salt stress. J. Plant Physiol. 183, 54-63.

Jelenska, J., Yao, N., Vinatzer, B.A., Wright, C.M., Brodsky, J.L., Greenberg, J.T., 2007. AJ domain virulence effector of Pseudomonas syringae remodels host chloroplasts and suppresses defenses. Curr. Biol. 17, 499-508.

Jiménez-Bremont, J.F., Marina, M., de la Luz Guerrero-González, M., Rossi, F.R., Sánchez-Rangel, D., Rodríguez-Kessler, M., Ruiz, O.A., Gárriz, A., 2014. Physiological and molecular implications of plant polyamine metabolism during biotic interactions. Front. Plant. Sci. 5, 95.

Karpiński, S., Szechyńska-Hebda, M., Wituszińska, W., Burdiak, P., 2013. Light acclimation, retrograde signalling, cell death and immune defences in plants. Plant Cell Environ. 36, 736-744.

Li, Z., Zhou, H., Peng, Y., Zhang, X., Ma, X., Huang, L., Yan, Y., 2015. Exogenously applied spermidine improves drought tolerance in creeping bentgrass associated with changes in antioxidant defense, endogenous polyamines and phytohormones. Plant Growth Regul. 76, 71-82.

Lillo, C., Meyer, C., Lea, U.S., Provan, F., Oltedal, S., 2004. Mechanism and importance of post-translational regulation of nitrate reductase. J. Exp. Bot. 55, 1275-1282.

Liu, P.P., von Dahl, C.C., Klessig, D.F., 2011. The extent to which methyl salicylate is required for signaling systemic acquired resistance is dependent on exposure to light after infection. Plant Physiol. 157, 2216-2226.

Mishina, T.E., Zeier, J., 2007. Pathogen-associated molecular pattern recognition rather than development of tissue necrosis contributes to bacterial induction of systemic acquired resistance in Arabidopsis. Plant J. 50, 500-513.

Moschou, P.N., Wu, J., Cona, A., Tavladoraki, P., Angelini, R., RoubelakisAngelakis, K.A., 2012. The polyamines and their catabolic products are significant players in the turnover of nitrogenous molecules in plants. J. Exp. Bot. 63, 5003-5015.

Németh, N., Janda, T., Horváth, E., Páldi, E., Szalai, G., 2002. Exogenous salicylic acid increases polyamine content but may decrease drought tolerance in maize. Plant Sci. 162, 569-574.

Planas-Portell, J., Gallart, M., Tiburcio, A.F., Altabella, T., 2013. Copper-containing amine oxidases contribute to terminal polyamine oxidation in peroxisomes and apoplast of Arabidopsis thaliana. BMC Plant Biol. 13, 109.

Poór, P., Gémes, K., Horváth, F., Szepesi, Á., Simon, M.L., Tari, I., 2011. Salicylic acid treatment via the rooting medium interferes with stomatal response, $\mathrm{CO}_{2}$ fixation rate and carbohydrate metabolism in tomato, and decreases harmful effects of subsequent salt stress. Plant Biol. 13, 105-114.

Poór, P., Kovács, J., Szopkó, D., Tari, I., 2013. Ethylene signaling in salt stress-and salicylic acid-induced programmed cell death in tomato suspension cells. Protoplasma 250, 273-284.

Poór, P., Kovács, J., Borbély, P., Takács, Z., Szepesi, Á., Tari, I., 2015. Salt stress-induced production of reactive oxygen- and nitrogen species and cell death in the ethylene receptor mutant Never ripe and wild type tomato roots. Plant Physiol. Biochem. 97, 313-322.

Quinet, M., Ndayiragije, A., Lefèvre, I., Lambillotte, B., Dupont-Gillain, C.C., Lutts, S. 2010. Putrescine differently influences the effect of salt stress on polyamine metabolism and ethylene synthesis in rice cultivars differing in salt resistance. J. Exp. Bot. 61, 2719-2733.

Romero-Puertas, M.C., Perazzoli, M. Zago, E.D. Delladonne, M. 2004. Nitric oxide signalling functions in plant-pathogen interactions. Cell. Microbiol. 6, 795-803.

Saha, J., Brauer, E.K., Sengupta, A., Popescu, S.C., Gupta, K., Gupta, B., 2015. Polyamines as redox homeostasis regulators during salt stress in plants. Front. Environ. Sci. 3, 21.

Serafini-Fracassini, D., Di Sandro, A., Del Duca, S., 2010. Spermine delays leaf senescence in Lactuca sativa and prevents the decay of chloroplast photosystems. Plant Physiol. Biochem. 48, 602-611.

Szepesi, Á., Csiszár, J., Gémes, K., Horváth, E., Horváth, F., Simon, L.M., Tari, I., 2009. Salicylic acid improves acclimation to salt stress by stimulating abscisic aldehyde oxidase activity and abscisic acid accumulation, and increases $\mathrm{Na}+$ content in leaves without toxicity symptoms in Solanum lycopersicum L. J. Plant Physiol. 166, 914-925.

Tada, Y., Spoel, S.H., Pajerowska-Mukhtar, K., Mou, Z., Song, J., Wang, C., Zuo, J., Dong, X., 2008. Plant immunity requires conformational changes of NPR1 via Snitrosylation and thioredoxins. Science 321, 952-956.

Van den Burg, H.A., Takken, F.L., 2009. Does chromatin remodeling mark systemic acquired resistance? Trends Plant Sci. 14, 286-294.

Yaakoubi, Y., Hamdani, S., Bekalé, L., Carpentier, R., 2014. Protective action of spermine and spermidine against photoinhibition of photosystem I in isolated thylakoid membranes. PloS One 9, e112893. http://dx.doi.org/10.1371/ journal.pone.0112893.

Yoda, Y., Yamaguchi, Y., Sano, H., 2003. Induction of hypersensitive cell death by hydrogen peroxide produced through polyamine degradation in tobacco plants. 
Plant Physiol. 132, 1973-1981.

Yoda, H., Hiroi, Y., Sano, H., 2006. Polyamine oxidase is one of the key elements for oxidative burst to induce programmed cell death in tobacco cultured cells. Plant Physiol. 142, 193-206.

Yun, B.W., Skelly, M.J., Yin, M., Yu, M., Mun, B.G., Lee, S.U., Hussain, A., Spoel, S.H., Loake, G.J., 2016. Nitric oxide and S-nitrosoglutatione function additively during plant immunity. New Phytol. http://dx.doi.org/10.1111/nph.13903.

Zeier, J., Pink, B., Mueller, M.J., Berger, S., 2004. Light conditions influence specific defence responses in incompatible plant-pathogen interactions: uncoupling systemic resistance from salicylic acid and PR-1 accumulation. Planta 219, $673-683$.

Zhang, X., Shen, L., Li, F., Meng, D., Sheng, J., 2011. Methyl salicylate-induced arginine catabolism is associated with up-regulation of polyamine and nitric oxide levels and improves chilling tolerance in cherry tomato fruit. J. Agr. Food Chem. 59, 9351-9357. 